\title{
Publisher Correction: The default network of the human brain is associated with perceived social isolation
}

R. Nathan Spreng (D), Emile Dimas, Laetitia Mwilambwe-Tshilobo, Alain Dagher (D), Philipp Koellinger (D), Gideon Nave (1), Anthony Ong, Julius M. Kernbach, Thomas V. Wiecki, Tian Ge, Yue Li (D), Avram J. Holmes (D), B. T. Thomas Yeo, Gary R. Turner, Robin I. M. Dunbar (1) \& Danilo Bzdok (1)

Correction to: Nature Communications https:/doi.org/10.1038/s41467-020-20039-w, published online 15 December 2020.

The original version of this Article contained an error in the Peer review information. The Peer review information section originally incorrectly read:

"Nature Communications thanks Meghan Meyer, Theodore Satterthwaite and the other, anonymous, reviewer(s) for their contribution to the peer review of this work. Peer reviewer reports are available."

The correct version states:

"Nature Communications thanks Meghan Meyer, Theodore Satterthwaite and the other, anonymous, reviewer(s) for their contribution to the peer review of this work."

This has been corrected in both the PDF and HTML versions of the Article.

Published online: 21 May 2021

Open Access This article is licensed under a Creative Commons Attribution 4.0 International License, which permits use, sharing, adaptation, distribution and reproduction in any medium or format, as long as you give appropriate credit to the original author(s) and the source, provide a link to the Creative Commons license,
and indicate if changes were made. The images or other third party material in this article are included in the article's Creative Commons license, unless indicated otherwise in a credit line to the material. If material is not included in the article's Creative Commons license and your intended use is not permitted by statutory regulation or exceeds the permitted use, you will need to obtain permission directly from the copyright holder. To view a copy of this license, visit http://creativecommons.org/licenses/by/4.0/.

(C) The Author(s) 2021 